\title{
GURU: ANTARA PENDIDIK, PROFESI, DAN AKTOR SOSIAL
}

\author{
Warsono \\ Fakultas Ilmu Sosial dan Hukum Universitas Negeri Surabaya \\ Email: warsono@unesa.ac.id
}

\begin{abstract}
Abstrak
Menjadi guru berarti menyandang dua status sekaligus pada dirinya. Yakni, profesional dan pendidik. Tetapi, kedua status ini tidak hanya didasarkan kompetensi dedaktif-metodik saja. Sebab, ada ekspektasi sosial yang menjadi cita-cita ideal masyarakat. Sehingga, guru profesional bukan semata-mata berorientasi mendapatkan pekerjaan dan pendapatan yang layak, melainkan juga memiliki panggilan jiwa dan kesadaran humanis. Meskipun banyak pelatihan peningkatan profesi guru di berbagai jurusan kependidikan, tetapi prosesnya tidak banyak bermakna. Hal ini disebabkan cara berpikir guru yang materislistik. Oleh sebab itu, makna guru sebagai pekerjaan harus digeser pada posisinya sebagai aktor sosial yang saling berdialog dengan realitas sosialnya untuk menemukan berbagai solusi akan persoalan pendidikan.
\end{abstract}

Kata kunci: guru, pendidik, profesi, dan aktor sosial

\section{Abstract}

Being teacher means having double status namely professionals and educators. However, both of status are not only based on didaktic-methodical competence. There are social expectation coming from the society to be ideal people. Thus, professional teachers are not solely oriented to get a job and a decent income, but also has a soul and human consciousness. Although there are lot of training to improve the teaching profession in the various departments of education, most of them are meaningless. This is due to the way of teachers' thought which is materislistic. Therefore, the meaning of the teacher as the workers should be shifted in position as social actors who always engage in mutual dialogue with the social reality to formulate solutions toward issue of education.

Keywords: teacher, educator, profession, social actor

\section{Latar Belakang}

Ada wacana publik yang terlanjur beredar di kalangan masyarakat awam terkait tipologi profesi. Yakni, di dunia ini hanya ada dua profesi: guru dan non guru. Padahal, banyak profesi lainnya yang turut memberi sumbangan berharga pada peradaban umat manusia. Sebut saja, para peneliti misalnya. Mereka tergolong kaum intektual yang bekerja keras menghasilkan berbagai temuan dan berperan mengembangkan kemajuan ilmu pengetahuan. Diantara mereka ada yang berhasil mendapatkan hadiah nobel bergengsi tingkat internasional. Temuan-temuannya banyak membantu mengatasi masalah kehidupan hingga turut merubah peradaban.

Guru merupakan suatu pekerjaan yang mulia. Apabila, para guru melakukan tugasnya secara ikhlas dan berdasarkan suara hatinya, maka mereka sudah memiliki "tiket masuk surga". 
Apabila, guru dalam mendidik muridnya dilandasi dengan kasih sayang, maka mereka juga akan mendapat tambahan bonus dicintai oleh para muridnya. Dengan demikian, guru yang baik akan memperoleh tiga "gaji” sekaligus. Yaitu, "gaji” ekonomis (uang), "gaji” teologis (amal ibadah), dan "gaji” sosial (kesan dan ingatan yang baik dari para muridnya, paling tidak didoakan).

Sejarah bangsa Jepang memberikan kita pelajaran berharga terkait profesi guru. Di kala kota Hirosimma dan Nagasaki dijatuhi Bom Atom oleh tentara sekutu pada Agustus 1945, yang menewaskan ratusan ribu penduduk kedua kota itu, pertanyaan yang dilontar Kaisar Hirohito bukanlah berapa tentara yang masih hidup. Tetapi, berapa jumlah guru yang tersisa dan dapat diperankan membangun peradabannya. Fenomena historis ini menunjukan bahwa guru memiliki status dan peran yang sangat terhormat dalam suatu bangsa. Di sisi yang lain, menujukan bahwa cara berpikir seorang pemimpin bangsa harus jauh ke depan dengan meletakkan peran penting aspek pendidikan, sekaligus menjadikan guru sebagai ujung tombaknya. Sebagaimana dikatakan oleh Lyndon B Johson Presiden Amerika Serikat periode (1963-1969 ) bahwa: "all the problem can be solved with one word is education".

Pentingnya kepedulian terhadap aspek pendidikan juga ditegaskan dalam ajaran teologis. Sering kita dengar pernyataan_yang diimitasi dari pandangan John Locke_bahwa anak yang baru lahir bagaikan kertas puth (tabula rasa). Karena itu, anak harus dididik dengan cara mengisi kertas putih itu dengan pengetahuan sarat manfaat. Gardner (dalam Santrock, 2009) menyatakan bahwa setiap anak memiliki potensi multikecerdasan yang harus dibantu pengembangannya melalui pendidikan, sehingga bisa berkembang optimal. Van Eukul dan Kellog, Antropolog, telah melakukan penelitian terhadap anak manusia yang dibiarkan hidup diasuh oleh seekor binatang. Hasilnya, anak tersebut tidak mampu berkembang sebagaimana "manusia" umumnya (Haralambos \& Holborn, 2000). Anak itu berperilaku seperti biantang, human being-nya tidak bisa berkembang. Anak manusia hanya akan menjadi "manusia" apabila dia hidup dan dididik dalam lingkungan masyarakat. Dalam agama ditegaskan bahwa mendidik anak merupakan kewajiban orang tua yang diperintahkan oleh tuhannya.

Pada masyarakat modern yang ditandai dengan menguatnya ideologi kapitalisme, tentu saja pendidikan menjadi sarana utama untuk memanusiakan manusia agar terbebas dari paham yang cenderung dehumanis tersebut (Hartoko, 1985). Pendidikan adalah sarana mengembangkan potensi dan meningkatkan kualitas sumber daya manusia. Di tengah kontestasi global yang mulai mengakar hingga ke dunia berkembang, tampaknya kemajuan suatu bangsa tidak lagi ditentukan oleh banyaknya sumber daya alam, melainkan ditentukan oleh kualitas sumber daya manusianya. Oleh karena itu, bangsa yang maju sering 
menempatkan pendidikan menjadi bagian utama dalam proses pembangunan dengan memberikan anggaran yang lebih (extra founding) dibandingkan bidang-bidang lainnya.

\section{Budaya Bisu Peserta Didik}

Pentingnya pendidikan telah ditegaskan dalam Pembukaan UUD 1945 yang menyatakan bahwa salah satu tujuan negara adalah mencerdaskan kehidupan bangsa. Upaya mencerdaskan kehidupan bangsa ini tentunya memerlukan proses pendidikan. Pentingnya pendidikan ini juga ditegaskan dalam UU Nomor 20 Tahun 2003 tentang Sisdiknas. Yakni, pendidikan merupakan usaha sadar dan terencana untuk mewujudkan suasana belajar dan proses pembelajaran agar peserta didik secara aktif mengembangkan potensi dirinya untuk memiliki kekuatan spiritual keagamaan, pengendalian diri, kepribadian, ahlak mulia, serta ketrampilan yang diperlukan dirinya, masyarakat, bangsa, dan Negara.

Untuk menyelenggarakan proses pendidikan tersebut membutuhkan guru yang berperan sebagai pembimbing, motivator, dan stimulator bagi anak didiknya. Peserta didik perlu dibantu untuk mengembangkan potensi dirinya dengan cara dibimbing, dimotivasi, dan diberi stimulus dengan berbagai pertanyaan agar potensi intelektualnya terus berkembang. Setiap manusia dalam kodratnya adalah pembelajar yang cerdas. Mereka dianugrahi oleh Tuhan dengan rasa ingin tahu (curiosity) sebagai modal untuk mengembangkan intelektualnya. Rasa ingin tahu dalam bentuk bertanya ini menjadi ciri utama tiap manusia, sejak masa anakanak. Mereka akan menanyakan segala sesuatu yang belum diketahui sebelumnya dengan menggunakan kata tanya "apa" (what). Dalam perkembangan diri selanjutnya, mereka akan terus bertanya dengan kata tanya bagaimana (how) dan mengapa (why).

Namun, sebagian guru justru "membunuh" rasa ingin tahu itu dengan melekatkan kata "bodoh", "cerewet", "cari perhatian" dan label stigmatik lainnya kepada anak didiknya yang mengajukan rangkaian pertanyaan. Bahasa stigmatik yang buruk seperti ini harus dibuang jauhjauh dari ranah pendidikan. Anak didik yang bertanya, apalagi bertanya dengan kata tanya "apa" adalah hal yang alamiah. Karena, bentuk dorongan dari rasa ingin tahu sebagai bagian kodratnya sebagai manusia. Jika mereka mulai bertanya dengan menggunakan kata tanya "bagaimana" dan "mengapa" justru menunjukan bahwa dirinya tergolong cerdas, karena mampu mengkonstruksi pengetahuan-pengetahuan sebelumnya. Sebagaimana dikatakan oleh Vigotsky dan Piaget bahwa seseorang yang mampu membangun pengetahuan baru dengan cara mengkontruksi pengetahuan-pengetahuan sebelumnya tergolong anak yang berpotensi nalar cemerlang (Santrock, 2009). Klaim bahwa anak yang bertanya itu adalah anak "bodoh", menunjukkan gurunya salah dalam mengkonstruksi integritas diri dan ke-guru-annya. Karena, 
mengganggap bahwa guru sebagai satu-satunya sumber pengetahuan. Akibatnya, guru yang tidak mampu menjawab pertanyaan peserta didiknya dan melabeli kata "bodoh" hanyalah alat yang mujarab untuk mempertahankan statusnya, agar tidak terlihat "bodoh" di hadapan para peserta didiknya. Bahasa labeling negatif seperti ini tentunya akan mematikan rasa ingin tahu para anak didiknya, bahkan akan menjadikan para peserta didiknya menjadi malas berpikir, apalagi bertanya.

Menganggap peserta didik yang bertanya itu adalah orang "bodoh", turut melanggengkan terjadinya budaya bisu dalam pendidikan. Budaya bisu dalam pendidikan ini mendapat kritikan yang keras dari Paulo Freire. Menurutnya, budaya bisu seperti ini hanya menjadikan peserta didik sebagai kaum tertindas (sebagai objek pendidikan) yang tidak lagi peka terhadap realitas sosial di sekitarnya (Freire, 1984). Suasana belajar yang menakutkan, karena kekangan struktur kurikulum yang kaku dan sikap otoriter guru, menjadikan institusi pendidikan tidak lebih sebagai penjara (Illich, 2000).

Tragisnya, budaya bisu yang terjadi di tingkat persekolahan itu terus berlanjut hingga ke jenjang perguruan tinggi. Para mahasiswa kehilangan naluri untuk berdiskusi dan bertanya pada saat perkuliahan berlangsung. Proses belajar mengajar di perguruan tinggi yang idealnya berjalan dua arah (dialogis) dan dilandasi oleh prinsip kesetaraan dalam berpikir sehingga memberi ruang diskusi antara dosen dan mahasiswa, justru tidak terjadi, bahkan membeku dan menjadi sesuatu yang langka ditemukan. Mahasiswa telah kehilangan rasa ingin tahu dan daya kritisnya, sehingga proses belajar mengajar hanya berjalan searah. Dalam perkuliahan, mahasiswa hanya menunggu apa yang akan diberikan oleh dosennya, tanpa ada keinginan atau keberanian untuk bertanya apa yang ingin diketahuinya. Dalam proses perkuliahan jarang sekali muncul pertanyaan-pertanyaan kritis dari mahasiswa, apalagi pertanyaan radikal, "nakal", dan "liar", sebagai wujud dari rasa ingin tahu mereka yang tinggi. Budaya seperti ini tentu sangat tidak kondusif untuk melahirkan ide-ide besar yang bisa menorehkan jejak peradaban dan berkontribusi bagi perkembangan ilmu pengetahuan.

\section{Guru: Pendidik atau Profesi ?}

Sejak dikeluarkannya UU Nomor 14 Tahun 2005 tentang Guru dan Dosen, guru memiliki tambahan status sebagai profesi, bukan sekedar pendidik. Dalam Pasal 1 (1) dijelaskan bahwa guru adalah pendidik yang professional dengan tugas utama mendidik, mengajar, membimbing, mengarahkan, melatih, menilai, dan mengevauasi peserta didik pada pendidikan anak usia dini jalur pendidikan formal, pendidikan dasar, dan menengah. Penambahan status sebagai profesi (semoga bukan penggantian istilah pendidik) jelas 
membawa implikasi secara ekonomis. Sebab, profesi adalah pekerjaan yang dilakukan sebagai kegiatan pokok untuk menghasilkan nafkah hidup dan yang mengandalkan suatu keahlian. Oleh karena itu, seorang guru yang professional akan memperoleh pendapatan yang lebih jika dibanding dengan guru yang tidak professional.

Meningkatnya keuntungan ekonomis sebagai profesi guru, keinginan masyarakat untuk menjadi guru tampak semakin besar. Bahkan, guru yang ada juga bertambah semangat mengejar tunjangan profesi guru, walau secara kualitatif tidak disertai dengan peningkatan tanggungjawab profesinya. Dalam perbincangan sederhana, ada beberapa kolega yang ahli di bidang penelitian profesi keguruan seperti Ismet Basuki, Rosminingsih, dan lainnya mengatakan bahwa tidak ada perbedaan kinerja yang signifikan antara guru yang telah memperoleh tunjangan profesi dengan mereka yang belum memperolehnya. Justru para guru yang telah memperoleh tunjangan profesi juga tidak mengalami peningkatan kinerja profesinya.

Semangat mengejar tunjangan profesi guru tersebut diduga menjadi pendorong semakin meningkatnya peminat masuk ke lembaga pendidikan penghasil tenaga kependidikan (LPTK), termasuk di jurusan kependidikan pada Universitas Negeri Surabaya (Unesa). Rumor sosial yang muncul di masyarakat sekitar bahwa Unesa adalah institusi negeri yang kompeten mendidik para calon guru profesional. Bahkan, ada semacam kelakar di kalangan mereka bahwa Unesa adalah satu-satunya kampus berstatus "negeri” di Jawa Timur, karena ada lebel "negeri” dalam akronim lembaganya. Terlepas dari rumor dan kelakar ini, setidaknya memori kolektif mengenai Unesa begitu kuat merasuki rasionalitas masyarakat akan pilihan jenjang pendidikan tingginya. Tetapi, belakangan ini ada gejala yang unik terkait wacana profesi guru. Diberbagai perguruan tinggi swasta yang memiliki program studi kependidikan tampak mulai ramai peminatnya. Di tengah-tengah ini juga muncul suatu paradoks. Besarnya keinginan menjadi guru profesional justru tidak disertai dengan pemahaman mendalam tentang peranan ideal yang harus diemban oleh sosok guru. Ini tentu akan mereduksi makna profesi guru itu sendiri. Profesi guru yang tidak dilandasi oleh suara hati sebagai pendidik, justru akan merusak masa depan pendidikan itu sendiri.

Status profesi guru sejati menuntut peran sebagai teladan (panutan), ilmuwan, motivator, intelektual dan bersikap bijak (wisdom) bagi peserta didiknya. Tindakan dan ucapannya akan menjadi cerminan perilaku para peserta didiknya. Guru akan kesulitan menyuruh para siswanya berbuat baik, kalau dia sendiri perilakukanya tidak baik. Misalnya, guru yang suka berkata jorok, maka ia akan sulit melarang muridnya untuk tidak berkata jorok. Guru sulit melarang muridnya merokok, kalau ia sendiri merokok. Bagaimanapun, guru akan 
menjadi figur sentral bagi peserta didiknya dalam berperilaku. Memang ada paradok antara perbuatan yang baik dengan yang tidak baik. Perbuatan tidak baik, meskipun tidak perlu diteladankan akan mudah dilakukan. Namun, perbuatan yang baik, meskipun sudah diberi teladan belum tentu dilaksanakan.

Guru juga harus mampu menjadi ilmuwan dan intelektual dalam arti sebagai sumber ilmu, sumber pengetahuan, dan memberikan pencerahan bagi peserta didiknya. Guru menjadi tempat bertanya bagi orang yang tidak tahu, dan menjadi obor bagi mereka yang berada dalam kegelapan. Meskipun, tidak harus menjadikan dirinya superior yang menganggap bahwa gurulah yang paling benar. Sikap kaum ilmuwan dan intelektual adalah menghargai dan menghormmati perbedaan pendapat, dan menjunjung tinggi kebenaran atas dasar fakta dan logika yang sehat. Peran guru sebagai ilmuwan dan intelektual ini telah ada dalam pepatah Jawa. Yakni, guru itu digugu lan ditiru. Digugu berarti guru memiliki pengetahuan yang luas, sehingga bisa menjadi sumber informasi, dan penerang gelapnya alam pikiran. Ditiru, berarti guru memiliki moralitas dan integritas, sehingga perilakunya bisa dijadikan teladan.

Guru yang berperan sebagai motivator bagi para peserta didiknya berarti guru mampu memberikan gambaran tentang apa yang akan terjadi di masa depan. Rendahnya prestasi dari peserta didik juga tidak lepas dari rendahnya cita-cita mereka. Semisal, jangan salahkan peserta didik yang tidak mau belajar matematika, karena cita-citanya hanya ingin menjadi satpam. Bagi mereka tidak ada kaitannya antara matematika dengan satpam. Agar, bisa menjadi satpam tidak dibutuhkan prasyarat utama harus mendalami matematika. Cita-cita peserta didik semacam ini barangkali disebabkan kurangnya pemahaman mereka mengenai beragamnya jenis pekerjaan. Bahkan, mungkin didasarkan pada pemahaman mereka terhadap kondisi sosial dan kultural yang dialaminya. Pada kondisi inilah guru harus mampu menjadi motivator terhadap peserta didiknya, untuk membangun cita-citanya yang lebih tinggi dari orang tua ataupun masyarakat sekitarnya.

Motivasi menjadi hal yang sangat penting bagi prestasi seseorang. Ada rumus yang pernah dicanangkan oleh ITB, bahwa prestasi $=$ potensi + motivasi. Artinya, bahwa potensi itu tidak akan optimal hasilnya jika tidak didukung motivassi yang kuat. Sedangkan, keberhasilan $=$ prestasi + peluang + keberanian. Dari dua konsep tersebut, jelas bahwa ada faktor internal untuk menentukan keberhasilan, yaitu, motivasi dan keberanian. Tugas guru adalah membangkitkan motivasi dan menumbuhkan keberanian kepada siswa untuk memanfaatkan peluang yang ada.

Guru juga seorang profesional, dalam arti memiliki keahlian untuk menjadikan peserta didiknya sebagai seorang pembelajar. Profesionalitas guru ini telah ditegaskan dalam UU No. 
20 Tahun 2005 tentang Guru dan Dosen. Menurut undang-undang tersebut untuk menjadi guru tidak cukup dengan ijasah sarjana (S1 dan D4), tetapi harus mengikuti pendidikan profesi guru (PPG). Sebagai seorang profesional, guru dituntut menguasai berbagai metode dan model pembelajaran, serta melaksanakan pembelajaran yang aktif, efektif, dan menyenangkan para peserta didiknya. Kemuliaan status guru ditentukan oleh terlaksananya peran yang memang secara inheren melekat padanya. Dampak dari tindakannya juga dirasakan oleh masyarakat luas, dan tindakan itu harus terus menerus dilakukan dengan lapang dada.

\section{Guru Sebagai Aktor Sosial}

Karakter guru berbeda dengan profesi lainnya, seperti pedagang, teknisi, maupun militer. Guru dalam arti pendidik berbeda dengan tutor, pelatih (trainer). Meskipun, profesi guru sebagai pendidik membutuhkan pendidikan dan pelatihan, tetapi profesi pendidik tidak sekedar hanya berkaitan dengan hard skill, tetapi lebih banyak berkaitan dengan soft skill (karakter). Inilah yang membedakan profesi guru dengan profesi-profesi lainnya. Diantara soft skill yang harus dimiliki oleh guru adalah keikhlasan, kasih sayang, dan idealisme untuk mendidik (Lickona, 1992). Agar, peserta didiknya kelak bisa menjadi orang-orang yang bermanfaat bagi agama, bangsa, Negara, keluarga dan masyarakatnya. Hal ini pernah diungkapkan oleh M. Nuh saat diundang ke acara Dies natalis Unesa tahun 2004 silam, waktu itu ia masih menjabat Rektor ITS (sebelum menjadi menteri pendidikan di era presiden SBY). Hal tersebut merupakan prinsip mendasar yang harus dimiliki oleh seorang pendidik, sebagaimana yang dijelaskan dalam Pasal 7 (a), dan (b) Undang-Undang Guru dan Dosen. Tanpa panggilan jiwa, idealisme, dan komitmen menjadi pendidik dari para guru, maka pendidikan bangsa ini tidak akan menghasilkan manusia-manusia yang cerdas secara intelektual, cerdas secara sosial, dan cerdas secara spiritual, atau manusia yang utuh atau manusia yang benar-benar manusia, melainkan hanya akan menghasilkan manusia-manusia yang serakah, egois, dan kejam.

Meskipun, guru sekarang menjadi profesi, tetapi statusnya sebagai pendidik masih tetap melekat, tidak bisa ditinggalkan begitu saja. Bisa ditegaskan bahwa status sebagai pendidik itu menjadi prasyarat bagi penunjang profesionalitas guru. Seperti yang ditegaskan dalam UU guru dan dosen No.14 Tahun 2005 Pasal 1 (1) bahwa guru adalah pendidik yang profesional. Secara Sosiologi humanis, panggilan jiwa seorang guru bisa dilihat dari motivasi mereka menjadi guru, baik motivasi yang mendorongnya (because motive) dan motivasi yang diharapkannya (in order motive). Kedua motif subjektif ini akan sangat menentukan profesionalitasnya sebagai seorang guru yang berdedikasi tinggi bagi masa depan pendidikan. 
Guru adalah aktor sosial yang memiliki kesadaran diri, sebagai subyek dan sekaligus bisa menjadikan dirinya sebagai obyek. Pembelajaran yang dilakukannya berdasarkan tindakan sosial (action) yang bernilai rasionalitas nilai dan kepercayaan (belief) yang menjadi konvensi sosial. Oleh karena itu, upaya untuk meningkatkan profesionalitas guru harus dilakukan dengan cara melibatkan peran serta guru, untuk mengidentifikasi persoalan pada diri mereka agar ditemukan solusinya. Tindakan sosial melibatkan orang lain sebagai proses konstruksi makna, sehingga perlu ada dialog dengan pihak lain agar makna pendidikan sebagai modal sosial mampu tercapai sesuai harapan masyarakat (Farley, 1990).

Tindakan sosial yang dilakukan seseorang tidak bisa lepas dari pengetahuan yang mereka miliki dalam kehidupan sehari-hari. Keyakinan apriori guru bahwa cara mengajar yang mereka lakukan selama ini sudah baik, tentu juga bagian yang harus diubah. Guru harus kreatif dan terus belajar untuk meningkatkan kedalaman pengetahuannya (Schunk, 2004). Baik itu pengetahuan kompetensi pembelajarannya, media yang digunakan, hingga perkembangan ilmu pengetahuan dalam wacana intelektual kontemporer. Untuk meningkatkan kompetensi pembelajaran misalnya diperlukan metode PAIKEM yang ditawarkan oleh Agus Suprijono (2010), tapi syarat dasarnya guru dituntut terus kreatif dan berpikir cerdas. Terus belajar meningkatkan pengetahuannya merupakan kesadaran yang patut dilestarikan, supaya menghasilkan para pembelajar yang aktif, kreatif, kritis, dan futuristik.

Berdasarkan pengalaman pribadi di lapangan, pemahaman para guru mengenai status dan peran yang harus dilakukan masih sangat kabur. Pemahanan mereka sebatas pada tugas dedaktif-metodik, dan pemahaman mendidik yang sangat abstrak, karena belum dijabarkan secara lebih oprasional dalam bentuk tindakan nyata. Pengalaman penulis ketika berdialog dengan para guru saat proses Pendidikan dan Latihan Profesi Guru (PLPG) menunjukan bahwa mereka senyatanya setuju bahwa guru merupakan status yang mulia. Ketika ditanya peran yang harus dilakukan oleh guru, hampir semuanya tidak mampu memberi jawaban yang jelas. Ketika ditanya kompetensi yang harus dimiliki oleh seorang guru, mereka umumnya serentak menjawab dengan mengkait-kaitkan pada empat kompetensi sebagaimana didasarkan pada UU guru dan Dosen: kompetensi professional, kompetensi pedagogik, kompetensi sosial, dan kompetensi personal. Mulai semakin penasaran, saya lantas bertanya tentang indicator untuk mengukur empat kompetensi tersebut. Hasilnya, hampir semuanya tidak bisa memberi jawaban rasional. Secara simbolik, mereka juga tidak bisa menjawab secara tegas berkenaan pelaksanaan kompetensi itu dalam dunia profesinya.

Fakta ini menunjukan bahwa persoalan profesionalitas guru sering mengabaikan dimensi etika dan estetika dalam proses pendidikan. Etika bukan masalah berburu pada juklak- 
juknis. Lebih dari itu, etika terkait dengan panggilan jiwa untuk berpegang pada nilai-nilai humanitas, keadilan, dan altruisme sosial. Sedangkan, estetika pendidikan bukan persoalan penyeragaman melainkan seni mendidik manusia unik dan beragam psiko-sosialnya yang dipercayakan agama, keluarga, negara, dan masyarakat kepadanya. Persoalannya tidak semua guru yang ada sekarang motivasinya sunguh-sungguh menjadi pendidik sebagai panggilan jiwanya, melainkan lebih banyak pada orientasi pendapatan (pekerjaan). Jika demikian adanya, maka berbagai program pendidikan dan pelatihan yang dilakukan oleh berbagai pihak (baik institusi negeri ataupun swasta) sepertinya tidak akan banyak bermakna terhadap peningkatan profesionalitas guru. Cobalah sesekali mendengarkan suara masyarakat di warung makan yang membicarakan tentang sertifikasi guru. Nada mereka akan lebih terdengar kritis dibandingkan kebanyakan para guru itu sendiri, karena tiap menerima sertifikasi guru justru berbagai tempat perbelanjaan yang akan mereka tuju daripada toko-toko buku. Lebih dari itu, jumlah kendaraan pribadinya tiba-tiba bertambah daripada langganan koran dan jurnal ilmiah bertema pendidikan yang senyatanya akan lebih bermanfaat bagi peningkatan kapasitas pengetahuannya berjangka panjang.

\section{Kesimpulan}

Oleh sebab itu, meningkatkan profesionalitas guru di dunia pendidikan adalah merubah konstruksi mereka tentang status dan peran yang harus dilakukannya. Mereka harus disadarkan mengenai apa yang seharusnya dilakukan sebagai konsekuensi dari status sebagai pendidik yang profesional. Mereka memang perlu harus diberi sanksi yang tegas, jika mereka tidak mengalami perubahan diri menjadi lebih baik. Sementara, bagi guru dalam jabatan yang sudah tersertifikasi, harus perlu dievaluasi secara berkala untuk merubah motivasi mereka dari orientasi materialisme ke orientasi idealisme sebagai sosok pendidik. Sedangkan, bagi guru prajabatan, seleksinya harus mengutamakan seberapa besar panggilan jiwanya untuk menjadi pendidik yang humanis, kritis, kreatif, dan altruistik. Setidaknya, ciri minimal panggilan jiwa pendidik yang demikian ini bisa ditunjukan dengan motivasi awal mereka menjadi guru saat hendak berkuliah di jurusan sarjana kependidikan pada perguruan tinggi.

\section{Referensi}

Farley, E. John. 1990. Sociology. New Jersey: Prentice-Hall, Inc.

Freire, Paulo, 1984. Pendidikan Sebagai Praktek Pembebasan. Jakarta: Gramedia

Haralambos Michael and Holborn Martin. 2000. Sociology Themes and Perspectives. Fifth edition. London: Harper Collins Publishers Limited. 
Hartoko, Dick. (ed.). 1985. Memanusiakan Manusia Muda. Yogyakarta: Kanisius.

Illich, Ivan. 2000. Bebaskan Masyarakat dari Belenggu Sekolah. Jakarta: YOI

Lickona, Thomas. 1992. Educating for Character. New York: Bantam Books.

Santrock, W. John. 2009. Educational Psychology (fourth edition). New York: McGrawHill.

Schunk, H. Dale. 2004. Learning Theories An Educational perspective. United States of America: Pearson Prentice Hall.

Suprijono, Agus. 2010. Cooperative Learning: Teori dan Aplikasi PAIKEM, Yogyakarta: Pustaka Pelajar 